\title{
Pullout Bond Failure Load of Corroded and Coated Members in Corrosive Media
}

\author{
Toscanini Dein Seimodei ${ }^{1}$, Gede Tariebibo Enai ${ }^{2}$, Charles Kennedy ${ }^{3}$ \\ ${ }^{1}$ Faculty of Engineering, Department of Civil Engineering, Niger Delta University, \\ Wilberforce Island, Bayelsa State \\ ${ }^{2}$ Faculty of Engineering, Department of Civil Engineering, University of Africa, \\ Bayelsa State \\ ${ }^{3}$ Faculty of Engineering, Department of Civil Engineering, Rivers State University, \\ Nkpolu, Port Harcourt, Nigeria.
}

E-mail: ${ }^{1}$ toscanini1468@yahoo.com, ${ }^{2}$ tariebibogede@gmail.com, ${ }^{3}$ ken_charl@yahoo.co.uk

\section{ABSTRACT}

Chloride and carbonation contamination presence in marine zones of Niger Delta of Nigeria are primary causes of poor bonding between steel reinforcement and concrete that has led to premature deterioration in reinforced concrete structures in the harshly environments. This work experimented the used of environmentally friendly corrosion inhibitors of exudates/resin from natural origin. Reinforcing steel bars were coated with varying thickness of $150 \mu \mathrm{m}, 300 \mu \mathrm{m}$ and $450 \mu \mathrm{m}$ against non-coated and embedded in concrete cubes, cured in accelerated corrosive media and investigated pull-out bond strength parameters. Obtained results summarized into 3.4 and 3.5, as shown in figures $3.1-3.4$, of corroded are average failure bond load of corroded members as $15.743 \mathrm{kN}, 15.7766 \mathrm{kN}$ and $15.716 \mathrm{kN}$, summed to $15.74555 \mathrm{kN}$ represented $-44.2130 \%$ against $79.25340 \%$ and $83.24747 \%$ percentile difference of control and coated exudates/resin member. Bond strength load corroded are $5.7133 \mathrm{MPa}$, 5.89333MPa, 5.71666MPa summed to 5.7244MPa, represented percentile value of $-33.474 \%$ against $50.31749 \%$ and $50.31749 \%$ percentile difference control and coated and maximum slip corroded average values are $0.16173 \mathrm{~mm}, 0.0795333 \mathrm{~mm}, 0.07586 \mathrm{~mm}$, summed to $0.075866 \mathrm{~mm}$, represented $-28.949 \%$ against $40.74399 \%$ and $129.8769 \%$ percentile difference of control and coated. Relatively, results of corroded specimens decreased while control and cola acuminata exudates/ resins steel bar coated specimens increased resulted due to layered bonding agent properties of exudate specimens. Entire results showed that natural exudates/resins should be explored as inhibitors to corrosion effects in steel reinforcement in concrete structure in chloride expected regions.

Key Words: Corrosion, Corrosion inhibitors, Pull-out Bond Strength, Concrete and Steel Reinforcement

\section{INTRODUCTION}

Corrosion is one of the main causes for the limited durability of reinforced concrete structures founded in the severe marine coastal region. General acceptance has it that corrosion of reinforcing steel is the primary causes of poor bonding between steel reinforcement and concrete that has led to premature deterioration in reinforced concrete structures. Chloride and carbonation contamination of reinforced concrete structures are the primary causes of steel corrosion that has resulted to manifestation in the reduction of bar diameter, wear and tear of mechanical properties of steel reinforcement. The effect of deteriorations, failures usually occurred and acceralated in reinforced concrete structures exposed to costal marine 
and harsh environments. Reinforced concrete structures built within the marine environment are at risk due to chloride-induced corrosion of reinforcement which resulted from the presence of high chloride concentrations and humid or saturated conditionse. Bond strength influenced by bar geometries, concrete properties, the presence of confinement around the bar, as well as surface conditions of the bar [1].

[2] investigated the effect of corroded and inhibited reinforcement on the stress generated on pullout bond splitting of Control, corroded and resins / exudates paste coated steel bar. Results obtained showed potentiality of corrosion on uncoated concrete cube members. In comparison, failure loads of Symphonia globulifera linn, Ficus glumosa, Acardium occidentale 1 are $36.47 \%, 32.50 \%$ and $29.59 \%$ against $21.30 \%$ corroded, bond strength are $64.00 \%, 62.40 \%, 66.90$ against $38.88 \%$ and maximum slip are $89.30 \%, 84.20 \%, 74.65 \%$ against $32.00 \%$ corroded. Entire results showed values increased in coated compared to corroded specimens resulted to adhesion properties from the resins / exudates also enhances strength to reinforcement and serves as protective coat against corrosion.

[3] Studied on the bond behavior of corroded reinforcement bars and have found that when the mass loss of the reinforcement due to corrosion reaches approximately $2 \%$, concrete cracks along the bar. A small amount of corrosion increases both the bond strength and bond stiffness, but the slip at failure decreases considerably. However, they stated that when the mass loss exceeds $2 \%$, bond stiffness decreases considerably.

[4] Investigated the effect of the diameter of the steel bar, and the thickness of the cover on the degree of corrosion of mild steel bars embedded in mortar. They found that there is a significant effect of rebar diameter, cover thickness, and specimen size on the corrosion intensity.

[5] Studied and evaluated the effect of corrosion on bond existing between steel and concrete interface of corroded and resins / exudates coated reinforcement with ficus glumosa extracts from trees. Experimental samples were subjected to tensile and pullout bond strength and obtained results indicated failure load, bond strength and maximum slip values of coated were higher by $33.50 \%, 62.40 \%, 84.20 \%$, non- corroded by $27.08 \%, 55.90 \%$ and $47.14 \%$ respectively. For corroded cube concrete members, the values were lower by $21.30 \%$, $38.80 \%$ and $32.00 \%$ on failure load, bond strength and maximum slip to those ones obtained by Control and coated members. The entire results showed good bonding characteristic and effectiveness in the use of ficus glumosa resins / exudates as protective materials against corrosion.

[6] investigated the primary causes of the reduction of service life, integrity and capacity of reinforced concrete structures in the marine environment of saline origin is corrosion. Results obtained on comparison showed failure bond load, bond strength and maximum slip decreased in corroded specimens to $21.30 \%, 38.80 \%$ and $32.00 \%$ respectively, while coated specimens $51.69 \%, 66.90 \%, 74.65 \%$, for Control specimen, $27.08 \%, 55.90 \%$ and $47.14 \%$. Entire results showed lower percentages in corroded and higher in coated members. This justifies the effect of corrosion on the strength capacity of corroded and coated members.

[7] Investigated the Corrosion of steel reinforcement in concrete is one of the principal factor that caused the splitting failures that occurred between steel and concrete, the used of epoxy, resin/exudates has been introduced to curb this trend encountered by reinforced structures built within the saline environment. Results obtained showed presence of corrosion in 
uncoated members. Pullout bond strength test results of failure bond load, bond strength and maximum slip were $21.30 \%, 36.80 \%$ and $32.00 \%$ for corroded members, $36.47 \%, 64.00 \%$ and $49.30 \%$ for coated members respectively. The values of corroded members were lower compared to coated members. Results showed that resins / exudates enhances strength to reinforcement and serves as protective coat against corrosion.

[8] investigated the effectiveness of resin/exudates in corrosion prevention of reinforcement in reinforced concrete cubes. Results obtained indicated that the failure bond strength, pull out bond strength and maximum slip of the resin coated reinforced cubes were higher by (19\%), (84\%) and (112\%). respectively than those obtained from the controlled tests. Similar results were obtained for the maximum slip (the resin coated and Control steel members) had higher values of maximum slip compared to the cubes that had corroded steel reinforcements. For the corroded beam members, the failure bond strength, pull out bond strength and maximum slip of the resin coated reinforcements were lower by $(22 \%),(32 \%)$ and $(32 \%)$. respectively than those obtained from the controlled tests.

[9] Studied the bond strength exhibited by reinforcement embedded in concrete is controlled by corrosion effects. Pullout bond strength results of failure load, bond strength and maximum slip for dacryodes edulis are $75.25 \%, 85.30 \%, 97.80 \%$, moringa oleifera lam; $64.90 \%$, 66.39\%, 85.57\%, magnifera indica; 36.49\%, 66.30\% and 85.57\%, for Control, $27.08 \%, 5590 \%$ and $47.14 \%$ while corroded are $21.30 \%, 36.80 \%$ and $32.00 \%$. The entire results showed lower values in corroded specimens as compared to coated specimens, coated members showed higher bonding characteristics variance from dacryodes edulis (highest), moringa oleifera lam (higher) and magnifera indica (high) and coated serves as resistance and protective membrane towards corrosion effects.

[10] indicated that the cover over reinforcement has the most significant effect on the extent of rebar corrosion. This study investigate the effect of reinforcement corrosion and inhibitor on bond and pull out capacity of degraded and inhibited steel reinforcement and monitor significant changes on the surface conditions of steel reinforcing bars embedded in concrete.

\section{MATERIALS AND METHODS FOR EXPERINMENT Experimental Program}

The present study involves direct application of resins / exudates of trees extract known as inorganic inhibitor, coated on the reinforcing steel surface were studied in this test program. The main objective of this study was to determine the effectiveness of locally available surface-applied corrosion inhibitors under severe corrosive environments and with chloride contamination. The test setup simulates a harsh marine environment of saline concentration in the concrete in the submerged portion of the test specimens, corrosion activity of the steel cannot be sustained in fully immersed samples. The samples were designed with sets of reinforced concrete cubes of $150 \mathrm{~mm} \times 150 \mathrm{~mm} \times 150 \mathrm{~mm}$ with a single ribbed bar of 12 $\mathrm{mm}$ diameter embedded in the centre of the concrete cube specimens for pull out test and was investigated. To simulate the ideal corrosive environment, concrete samples were immersed in solutions $(\mathrm{NaCl})$ and the depth of the solution was maintained.

\section{Aggregates}

The fine aggregate and coarse aggregate were purchased. Both met the requirements of [11]

\section{Cement}

Portland limestone cement grade 42.5 is the most and commonly type of cement in Nigerian Market. It was used for all concrete mixes in this investigation. The cement met the requirements of [12] 


\section{Water}

The water samples were clean and free from impurities. The fresh water used was gotten from the tap at the Civil Engineering Department Laboratory, Kenule Beeson Polytechnic, Bori, and Rivers State. The water met the requirements of [13]

\section{Structural Steel Reinforcement}

The reinforcements are gotten directly from the market in Port Harcourt [14]

\section{Corrosion Inhibitors (Resins / Exudates) Cola acuminata}

The study inhibitor (Cola acuminata) is of natural tree resins /exudates substance extracts.

\subsection{EXPERIMENTAL PROCEDURES Experimental method}

\section{Sample Preparation For Reinforcement With Coated Resin/Exudate}

Corrosion tests were performed on high yield steel (reinforcement) of $12 \mathrm{~mm}$ diameter with $550 \mathrm{~mm}$ lengths for cubes, Specimen surfaces roughness was treated with sandpaper / wire brush and specimens were cleaned with distilled water, washed by acetone and dried properly, then polished and coated with (Cola acuminata exudate), resin pastes with coating thicknesses of $150 \mu \mathrm{m}, 300 \mu \mathrm{m}$ and $450 \mu \mathrm{m}$ before corrosion test. The test cubes and beams were cast in steel mould of size $150 \mathrm{~mm} \times 150 \mathrm{~mm} \times 150 \mathrm{~mm}$. The specimens were cured at room temperature in the curing tanks for accelerated corrosion test process and testing procedure allowed for 120 days first crack noticed and a further 30 days making a total of 150 days for further observations on corrosion acceleration process.

\section{Accelerated Corrosion Set-Up And Testing Procedure}

In real and natural conditions the development of reinforcement corrosion is very slow and can take years to be achieved; as a result of this phenomenon, laboratory studies necessitate an acceleration of corrosion process to achieve a short test period. After curing the cubes specimens for 28 days, specimens were lifted and shifted to the corrosion tank to induce desired corrosion levels. Electrochemical corrosion technique was used to accelerate the corrosion of steel bars embedded in cubes specimens. Specimens were partially immersed in a $5 \% \mathrm{NaCl}$ solution for duration of 150 days, to examine the surface and mechanical properties of rebar.

\section{Pull-out Bond Strength Test}

The pull-out bond strength tests on the concrete cubes were performed 9 specimens each of non-corroded, corroded and exudates/resins coated specimens, totaling 27 specimens on Universal Testing Machine of capacity 50KN in accordance with BS EN 12390-2. The dimensions of the pull-out specimens were 27 cubes $150 \mathrm{~mm} \times 150 \mathrm{~mm} \times 150 \mathrm{~mm}$ with a single ribbed bar of $12 \mathrm{~mm}$ diameter embedded in the centre of the concrete cube. After 150 days, the accelerated corrosion subjected samples were examined to determine bond strength effects due to corrosion and corrosion inhibited samples. Specimens of $150 \mathrm{~mm} \times 150 \mathrm{~mm}$ $\mathrm{x} 150 \mathrm{~mm}$ concrete cube specimens were also prepared from the same concrete mix used for the cubes, cured in water for 28 days, and accelerated with $5 \% \mathrm{NaCl}$ solution for same 150 days making a total of 178 days was consequently tested to determine bond strength.

\section{Tensile Strength of Reinforcing Bars}

To ascertain the yield and tensile strength of tension bars, bar specimens of $12 \mathrm{~mm}$ diameter of Control, corroded and coated were tested in tension in a Universal Testing Machine and were subjected to direct tension until failure; the yield, maximum and failure loads being recorded. To ensure consistency, the remaining cut pieces from the standard length of corroded and Control steel bars were subsequently used in the bond and flexural test. 
EXPERIMENTAL RESULTS AND DISCUSSION

Tables 1, 2 and 3 are the detailed results of pullout bond strength test of failure bond load, bond strength and maximum slip obtained from 27 samples of control, corroded and cola acuminata exudates/ resins steel bar coated specimens paste on reinforcement embedded in concrete cubes member. Table 4 and 5 showed the results of average and summary pull-out bond strength values of failure load, bond strength and maximum slip of control, corroded and resins/exudates coated specimens. Fig. 1 and 2 are the plots of entire failure bond load versus bond strength and bond strength versus maximum slip, while figures 3 and 4 are the plots of average failure bond load versus maximum slip obtained from tables 1, 2 and 3.

\section{Control Concrete Cube Members}

From tables 1, the obtained results are summarized into 4 and 5 as presented in fig. $1-4$, failure bond load values average pullout out bond strength are $27.74 \mathrm{kN}, 28.6166 \mathrm{kN}$, $28.316 \mathrm{kN}$, summarized to $28.2244 \mathrm{kN}$, these showed $79.25340 \%$ percentile value, bond strength average values are $8.4 \mathrm{MPa}, 8.82 \mathrm{MPa}$ and $8.82 \mathrm{MPa}$, summarized to $8.68 \mathrm{MPa}$ and percentile value of $50.31749 \%$ recorded. Maximum slip average values are $0.1016 \mathrm{~mm}$, $0.11066 \mathrm{~mm}$, and $0.1080 \mathrm{~mm}$ summarized to $0.10677 \mathrm{~mm}$, represented percentile values of $40.74399 \%$

\section{Corroded Concrete Cube Members}

From table 2, obtained results are summarized into 4 and 5, as shown in fig. $1-4$, average failure bond load are $15.743 \mathrm{kN}, 15.7766 \mathrm{kN}$ and $15.716 \mathrm{kN}$, summed to $15.74555 \mathrm{kN}$ represented $-44.2130 \%$ against $79.25340 \%$ and $83.24747 \%$ percentile difference of control and coated exudates/resin member. Bond strength load are 5.7133MPa, 5.89333MPa, $5.71666 \mathrm{MPa}$ summed to $5.7244 \mathrm{MPa}$, represented percentile value of $-33.474 \%$ against $50.31749 \%$ and $50.31749 \%$ percentile difference control and coated and maximum slip average values are $0.16173 \mathrm{~mm}, 0.0795333 \mathrm{~mm}, 0.07586 \mathrm{~mm}$, summed to $0.075866 \mathrm{~mm}$, represented $-28.949 \%$ against $40.74399 \%$ and $129.8769 \%$ percentile difference of control and coated. Comparatively, results of corroded specimens decreased while control and cola acuminata exudates/ resins steel bar coated specimens increased resulted due to adhesive properties of controlled specimens ribbed reinforcement and exudates coated specimens.

\section{Cola Acuminata Exudates/ Resins Steel Bar Coated Specimens Steel Bar Coated Concrete}

\section{Cube Members}

Results from table 3 into 4 and 5, as shown in fig $1-4$, obtained failure bond load average values are $27.943 \mathrm{kN}, 29.256 \mathrm{kN}, 29.36 \mathrm{kN}$ summed to $29.36 \mathrm{kN}$, represented $83.24747 \%$ against $-44.2130 \%$ corroded percentile differences, bond strength average values are 12.21 MPa, $12.35 \mathrm{MPa}, 13.2066 \mathrm{MPa}$ summed to $28.8533 \mathrm{MPa}$, represented $50.31749 \%$ against $-33.474 \%$ and maximum slip values are $0.1534 \mathrm{~mm}, 0.16173 \mathrm{~mm}, 0.20806 \mathrm{~mm}$ summed to $0.17445 \mathrm{~mm}$ represented $129.8769 \%$ against $-28.949 \%$ corroded percentile differences. Entire results showed higher values of pullout bond strength in control and exudates/resin coated to corroded specimens. 
Table 1. Results of Pull-out Bond Strength Test ( $\tau u)$ (MPa)

\begin{tabular}{|l|l|c|c|c|c|c|c|c|c|c|}
\hline S/no & \multicolumn{9}{|c|}{ Control Cube Specimens } \\
\hline $\begin{array}{l}\text { Concrete } \\
\text { Cube }\end{array}$ & Sample & MAC & MBC & MCC & MDC & MEC & MFC & MGC & MHC & MIC \\
\hline MCJ1-1 & $\begin{array}{l}\text { Failure Bond } \\
\text { Loads (kN) }\end{array}$ & 28.48 & 27.62 & 27.12 & 29.33 & 27.83 & 28.69 & 28.83 & 27.63 & 28.49 \\
\hline MCJ1-2 & $\begin{array}{l}\text { Bond strength } \\
\text { (MPa) }\end{array}$ & 8.53 & 8.4 & 8.27 & 8.93 & 8.39 & 9.14 & 8.93 & 8.99 & 8.54 \\
\hline MCJ1-3 & $\begin{array}{l}\text { Max. slip } \\
\text { (mm) }\end{array}$ & 0.115 & 0.1 & 0.09 & 0.12 & 0.103 & 0.109 & 0.11 & 0.095 & 0.119 \\
\hline MCJ1-4 & $\begin{array}{l}\text { Bar diameter } \\
(\mathrm{mm})\end{array}$ & 12 & 12 & 12 & 12 & 12 & 12 & 12 & 12 & 12 \\
\hline
\end{tabular}

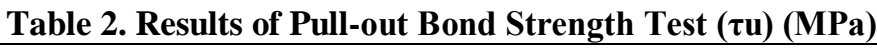

\begin{tabular}{|l|c|c|c|c|c|c|c|c|c|c|}
\hline S/no & \multicolumn{9}{|c|}{ Corroded Cube Specimens } \\
\hline $\begin{array}{l}\text { Concrete } \\
\text { Cube }\end{array}$ & Sample & MAC2 & MBC2 & MBC2 & MDC2 & MEC2 & MFC2 & MGC2 & MHC2 & MIC2 \\
\hline MCJ 2-1 & $\begin{array}{c}\text { Failure Bond } \\
\text { load (KN) }\end{array}$ & 15.32 & 16.07 & 15.84 & 16.3 & 15.55 & 15.48 & 16.07 & 15.55 & 15.53 \\
\hline MCJ 2-2 & $\begin{array}{c}\text { Bond strength } \\
\text { (MPa) }\end{array}$ & 5.33 & 5.98 & 5.83 & 6.35 & 5.79 & 5.54 & 5.95 & 5.64 & 5.56 \\
\hline MCJ 2-3 & $\begin{array}{c}\text { Max. slip } \\
\text { (mm) }\end{array}$ & 0.0572 & 0.0832 & 0.0762 & 0.0882 & 0.0752 & 0.0752 & 0.0812 & 0.0732 & 0.0732 \\
\hline MCJ2-4 & $\begin{array}{c}\text { Bar diameter } \\
(\mathrm{mm})\end{array}$ & 12 & 12 & 12 & 12 & 12 & 12 & 12 & 12 & 12 \\
\hline
\end{tabular}

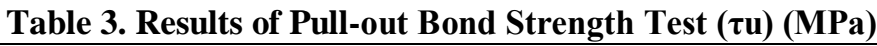

\begin{tabular}{|c|c|c|c|c|c|c|c|c|c|c|}
\hline & & \multicolumn{9}{|c|}{ Cola acuminata exudates ( steel bar coated specimen) } \\
\hline S/no & & \multicolumn{3}{|c|}{$(150 \mu m)$ coated } & \multicolumn{3}{|c|}{$(300 \mu \mathrm{m})$ coated } & \multicolumn{3}{|c|}{$(450 \mu \mathrm{m})$ coated } \\
\hline $\begin{array}{l}\text { Concrete } \\
\text { Cube }\end{array}$ & Sample & MAC3 & MBC3 & MBC3 & MDC3 & MEC3 & MFC3 & MGC3 & MHC3 & MIC3 \\
\hline MCJ3-1 & $\begin{array}{l}\text { Failure load } \\
(\mathrm{KN})\end{array}$ & 28.03 & 27.58 & 28.22 & 28.81 & 29.63 & 29.33 & 29.54 & 29.71 & 28.83 \\
\hline MCJ3-2 & $\begin{array}{l}\text { Bond strength } \\
\text { (MPa) }\end{array}$ & 12.58 & 12.78 & 11.27 & 11.78 & 12.58 & 12.69 & 13.68 & 12.98 & 12.96 \\
\hline MCJ3-3 & $\begin{array}{l}\text { Max. slip } \\
\text { (mm) }\end{array}$ & 0.1634 & 0.1534 & 0.1434 & 0.1604 & 0.1534 & 0.1714 & 0.1994 & 0.2134 & 0.2114 \\
\hline MCJ3-4 & $\begin{array}{c}\text { Bar diameter } \\
(\mathrm{mm})\end{array}$ & 12 & 12 & 12 & 12 & 12 & 12 & 12 & 12 & 12 \\
\hline
\end{tabular}

Table 4. Results of Average Pull-out Bond Strength Test ( $\tau u)$ (MPa)

\begin{tabular}{|c|c|c|c|c|c|c|c|c|c|c|}
\hline & & \multicolumn{9}{|c|}{ Control, Corroded and Resin Steel bar Coated } \\
\hline S/no & & \multicolumn{3}{|c|}{ Control Cube } & \multicolumn{3}{|c|}{ Corroded Cube Specimens } & \multicolumn{3}{|c|}{$\begin{array}{l}\text { Exudate steel bar coated } \\
\text { specimens }\end{array}$} \\
\hline $\begin{array}{l}\text { Concrete } \\
\text { Cube }\end{array}$ & Sample & \multicolumn{3}{|c|}{$\begin{array}{l}\text { Control Specimens } \\
\text { Average Values }\end{array}$} & \multicolumn{3}{|c|}{$\begin{array}{c}\text { Corroded Specimens Average } \\
\text { Values }\end{array}$} & \multicolumn{3}{|c|}{$\begin{array}{c}\text { Coated Specimens Average } \\
\text { Values of } 150 \mu \mathrm{m}, 300 \mu \mathrm{m}, \\
450 \mu \mathrm{m})\end{array}$} \\
\hline MCJ4-1 & $\begin{array}{l}\text { Failure load } \\
(\mathrm{KN})\end{array}$ & 27.74 & 28.6166 & 28.316 & 15.743 & 15.7766 & 15.716 & 27.943 & 29.256 & 29.36 \\
\hline MCJ4-2 & $\begin{array}{l}\text { Bond strength } \\
\quad(\mathrm{MPa})\end{array}$ & 8.4 & 8.82 & 8.82 & 5.7133 & 5.89333 & 5.71666 & 12.21 & 12.35 & 13.2066 \\
\hline MCJ4-3 & Max. slip (mm) & 0.1016 & 0.11066 & 0.108 & 0.0722 & 0.0795333 & 0.07586 & 0.1534 & 0.16173 & 0.20806 \\
\hline MCJ4-4 & $\begin{array}{l}\text { Bar diameter } \\
(\mathrm{mm})\end{array}$ & 12 & 12 & 12 & 12 & 12 & 12 & 12 & 12 & 12 \\
\hline
\end{tabular}


Table 5. Results of Average Pull-out Bond Strength Test ( $\tau u$ ) (MPa)

\begin{tabular}{|c|c|c|c|c|c|c|c|c|c|c|}
\hline & & $\begin{array}{l}\text { Summar } \\
\text { Values o } \\
\text { and Exuc }\end{array}$ & $\begin{array}{l}\text { Specimen } \\
\text { Control, } \\
\text { te Steel b }\end{array}$ & $\begin{array}{l}\text { Average } \\
\text { rroded } \\
\text { Coated }\end{array}$ & $\begin{array}{l}\text { Summal } \\
\text { Control }\end{array}$ & $\begin{array}{l}\text { of Percent } \\
\text { orroded a } \\
\text { eel bar Co }\end{array}$ & $\begin{array}{l}\text { Values of } \\
\text { d Exudate } \\
\text { ed }\end{array}$ & $\begin{array}{l}\text { Percentil } \\
\text { Corroded }\end{array}$ & $\begin{array}{l}\text { ifference } \\
\text { nd Exudat } \\
\text { Coated }\end{array}$ & $\begin{array}{l}\text { Control, } \\
\text { Steel bar }\end{array}$ \\
\hline $\begin{array}{c}\text { MCJ5- } \\
1\end{array}$ & $\begin{array}{c}\text { Failure } \\
\text { load }(\mathrm{KN})\end{array}$ & 28.2244 & 15.74555 & 28.8533 & 179.253 & 55.78694 & 183.2474 & 79.25340 & -44.2130 & 83.24747 \\
\hline $\begin{array}{c}\text { MCJ5- } \\
2\end{array}$ & $\begin{array}{c}\text { Bond } \\
\text { strength } \\
(\mathrm{MPa})\end{array}$ & 8.68 & 5.774444 & 12.5888 & 150.317 & 66.52585 & 218.0103 & 50.31749 & -33.474 & 118.0103 \\
\hline $\begin{array}{c}\text { MCJ5- } \\
3\end{array}$ & $\begin{array}{l}\text { Max. slip } \\
\text { (mm) }\end{array}$ & 0.10677 & 0.075866 & 0.1744 & 140.744 & 71.05098 & 229.87698 & 40.74399 & -28.949 & 129.8769 \\
\hline $\begin{array}{c}\text { MCJ5- } \\
4\end{array}$ & $\begin{array}{c}\text { Bar } \\
\text { diameter } \\
(\mathrm{mm})\end{array}$ & 12 & 12 & 12 & 100 & 100 & 100 & 0 & 0 & 0 \\
\hline
\end{tabular}

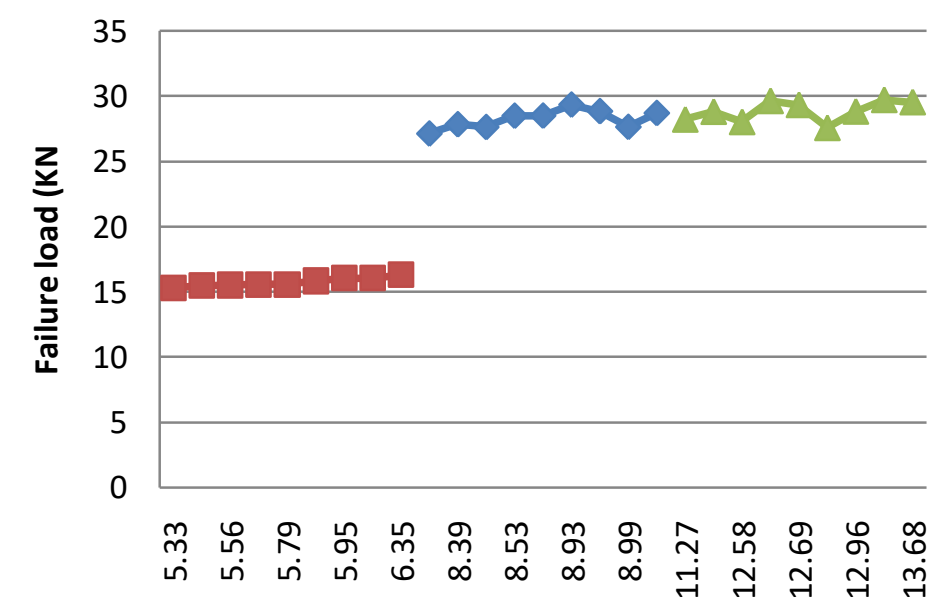

$\sim$ Control Cube Specimens

- Corroded Cube Specimens

- Cola acuminata exudates ( steel bar coated specimen) of $150 \mu \mathrm{m}, 300 \mu \mathrm{m}, 450 \mu \mathrm{m}$

Bond strength (MPa)

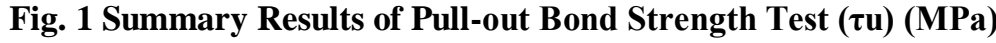

(Failure loads versus Figure Bond Strengths)

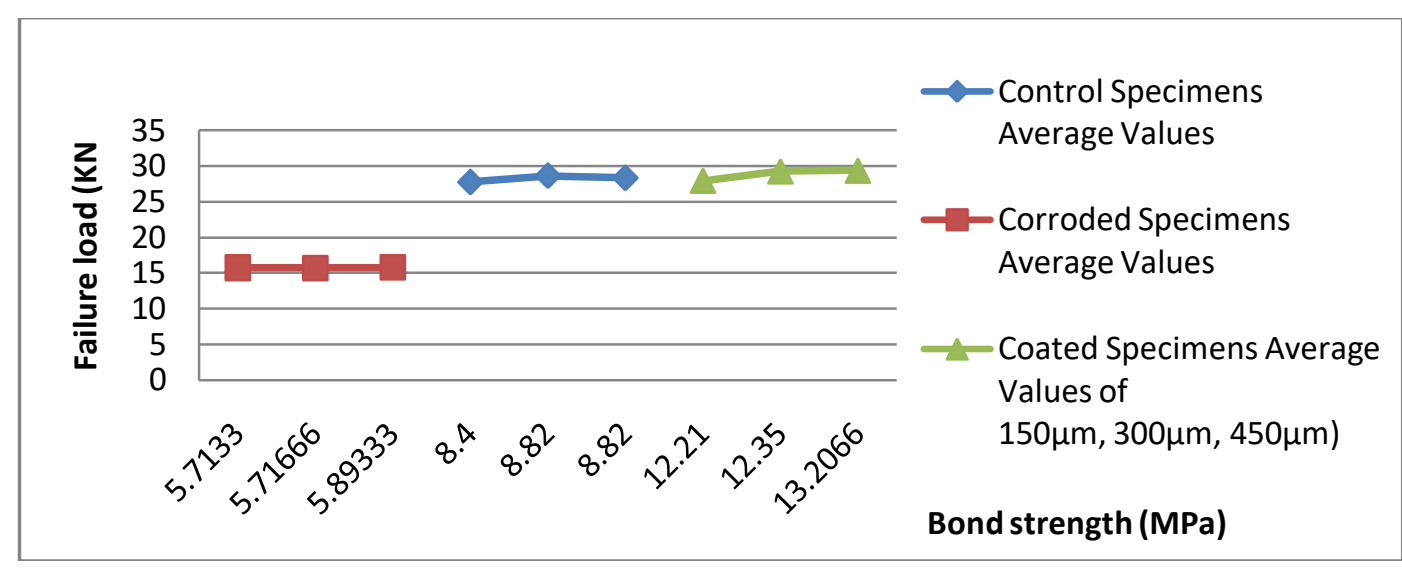

Fig. 2 Average Results of Pull-out Bond Strength Test ( $\tau u)$ (MPa) (Failure loads versus Bond Strengths) 


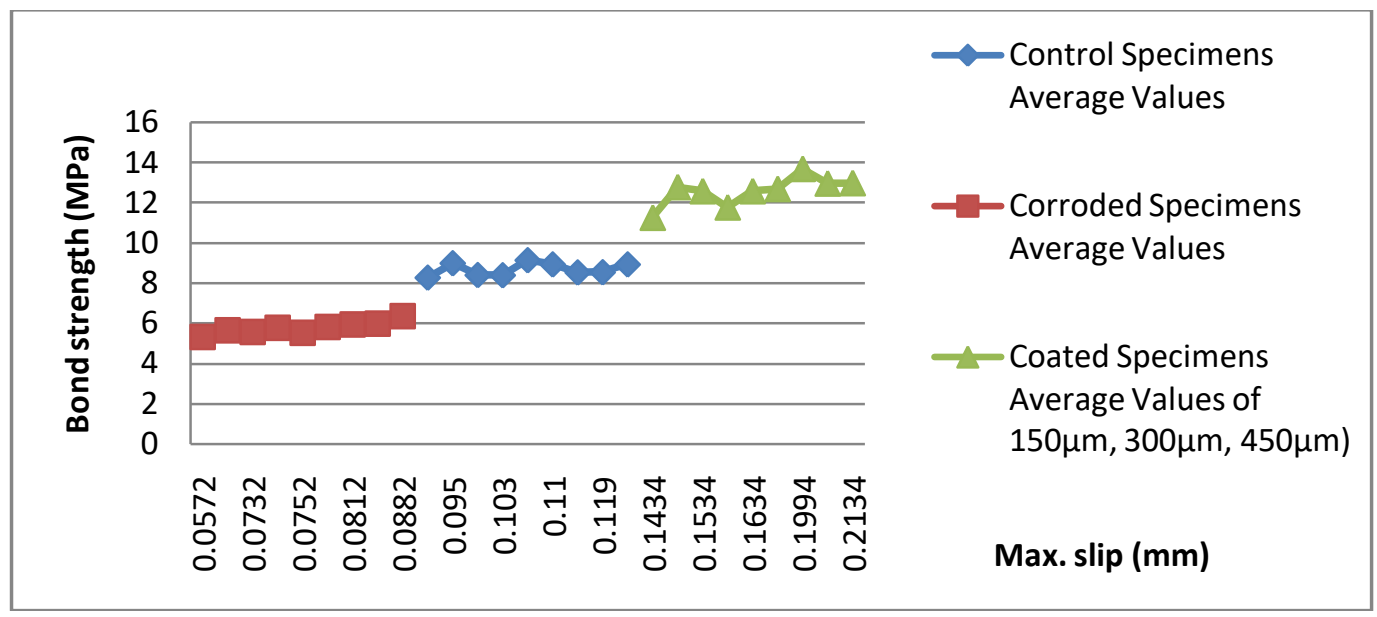

Fig. 3 Summary Results of Pull-out Bond Strength Test ( $\tau u$ ) (MPa) (Bond Strength versus Maximum Slip)

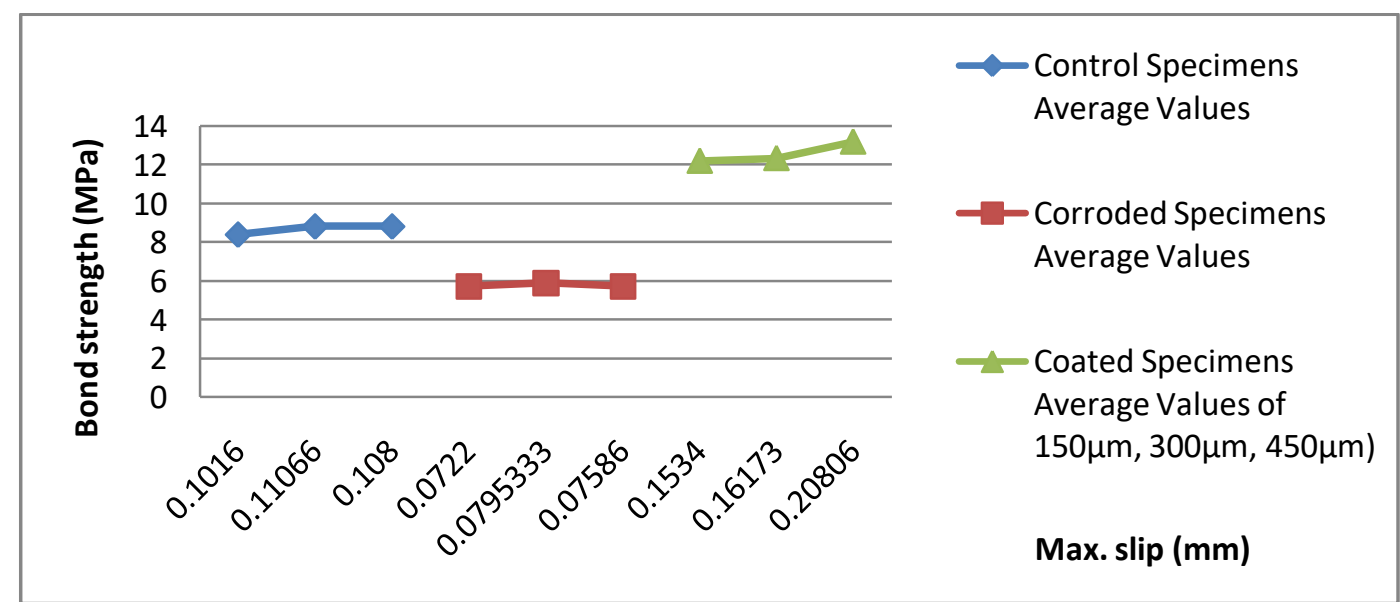

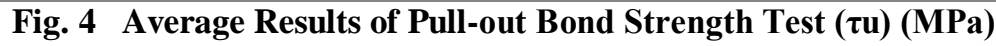
(Bond Strength versus Maximum Slip)

\section{CONCLUSION}

Experimental results showed the following conclusions:

i. Cola acuminata exudates/ resins coated specimens recorded higher pullout bond values

ii. Low pullout bond percentile values were recorded in corroded specimens

iii. Effects of corrosion on the strength capacity of corroded were recorded as higher failure bond load was experienced

iv. Summarized results showed higher values of pullout bond strength in control and exudates/ resins coated to corroded specimens

v. Bond test results showed, bond stresses experienced exudates/resin coated reinforcements are higher compared to the controlled specimens

\section{REFERENCES}

1. ACI. Bond and Development of Straight Reinforcing Bars in Tension: American Concrete Institute, Farmington Hills, MI. 2003.

2. K. Charles, L. P. Latam and K. Ugo. Effect of Corrosion on Bond between Steel and Concrete of Corroded and Inhibitive Reinforcement Embedded in Reinforced Concrete 
Structures in Accelerated Corrosive medium. International Journal of Scientific \& Engineering Research, vol.9, no.4, pp.803 - 813, 2018.

3. Y. Auyeung, P. Balaguru and L. Chung. Bond Behavior of Corroded Reinforcement Bars,ACI Materials Journal,vol.(97) 2, pp. 214-220, 2000.

4. R. Ravindrarajah and K. Ong. Corrosion of Steel in Concrete in Relation to Bar Diameter and Cover Thickness, ACI Special Publication, 100/4, pp.1667-1678, 1987.

5. K. Charles, I. S. Okabi, T. T. W. Terence, O. Kelechi. Comparative Investigation of PullOut Bond Strength Variance of Resins \Exudates Inhibitive and Corroded Reinforcement Embedded in Reinforced Concrete Structures, Exposed to Severely Environment.International Journal of Scientific \& Engineering Research, vol.9, no.4, pp. $641-654,2018$.

6. K. Charles, S. K. Gbinu and L. O. Achieme. Effect of Corrosive Environment on Reinforced Concrete Structures Pullout Bond Strength of Corroded and Resins / Exudates Coated Reinforcement. International Journal of Scientific \& Engineering Research, vol.9, no.4, pp. 814 - 824, 2018.

7. K. Charles, B. M. Akatah, O. Ishmael and P. P. Akpan. Pullout Bond Splitting Effects of Reinforced Concrete Structures with Corroded and Inhibited Reinforcement in Corrosive Environment of Sodium Chloride. International Journal of Scientific \& Engineering Research, vol.9, no.4, pp. 1123 - 1134, 2018.

8. K. Charles, S. K, Gbinu, E. I. Ogunjiofor and I. S. Okabi. Chloride Inducement on Bond Strength Yield Capacity of Uncoated and Resins / Exudates Inhibited Reinforcement Embedded in Reinforced Concrete Structures. International Journal of Scientific \& Engineering Research, vol.9, no.4, pp.874 -885, 2018.

9. A.W. Otunyo and C. Kennedy. Effectiveness of Resins/Exudates of Trees in Corrosion Prevention of Reinforcement in Reinforced Concrete structures. Nigerian Journal of Technology, no.37, pp.78-86, 2018.

10. F. H. Rasheeduzzafar, Dakhil, and A. S. Al-Gahtani. Corrosion Of Reinforcement in Concrete Structures in the Middle East, Concrete International; American Concrete Institute, vol.7, no. 9, pp. 48-55, 1985

11. BS. 882; Specification for aggregates from natural sources for concrete, British Standards Institute. London, United Kingdom, 1992.

12. BS EN 196-6; - Methods of Testing Cement. Determination of fineness, British Standards Institute. London, United Kingdom, 2010.

13. BS 3148 - Methods of test for water for making concrete. British Standards Institute.London, United Kingdom, 1980.

14. BS 4449:2005+A3 - Steel for Reinforcement of Concrete. British Standards Institute.London, United Kingdom, 2010 